\title{
研究のスポット
}

\section{天然グリセロール誘導体の 絶対配置の決定}

鵜沢浩隆, 大類 洋, 目黒 熙 東北大学農学部食糧化学科

天然に存在するグリセリド，グリセロリン脂質，グリ セ口糖脂質は，生体の構成成分として広く分布し，これ らはいずれもグリセロール骨格を持つ.このグリセロー ルは，分子内に対称面を有し，それ自体は光学不活性で ある.しかしグリセロールはプロキラルな化合物であ り， 1 位または 3 位（以下，sn一命名法*による）に置換 基が選抧的に導入されるか，あるいは，1 位または 3 位 の 2 つのチレン水素 $\left(-\mathrm{CH}_{2} \mathrm{OH}\right)$ の片方が他の置換基 に置きかわると光学活性体になる，生体反応において は,グリセロールの 1 位および 3 位は識別され，光学活 性なりン脂質やグリセロ脂質を与える(1).

生体脂質の大部分を占めるグリセリドの立体化学を明 らかにする研究は，一般に困難であった。それは，物理 化学的に 1 位と 3 位の識別が困難なこと, さらに光学活 性グリセリドの立体配置の決定が困難であったためであ る. 筆者らは，この問題点をキラル重水素化グリセリド を用いた NMR 法により解決し(2)，高感度な円二色性 (CD) の励起子キラリティー法に基づいた(3)グリセり ドの絶対配置の新しい決定法(4)，ならびに高分解能 $N M R^{(5)}$ 抗るび旋光分散(ORD)，CD を用いた糖グリ セリドの絶詨配置の決定法(6)を開発したので，以下に紹 介する。

\section{CD 法によるグリセリドの絶対配置の決定 ${ }^{(4)}$}

天然に存在するグリセりドの絶対配置を決定すること は，生合成経路の解明および生物活性と絶対配置との関 係を明らかにする上で重要である。これまでの絶詨配置 解析法は，酵素法拉よび物理化学的方法である非酵素法 に大別できる，前者においては，ホスホリパーゼによる

*グリセロールの炭素原子のナンバリング法. グリセロールの 2 番目の炭素に結合した水酸基を左側に配置させるよう Fischer 投影したとき，上位の炭素原子を C-1 とする.
立体特異的加水分解を利用した Brockerhoff 法(7)が今日 最も広く用いられている。また，後者の分析法には，化 学的誘導体化法, 比旋光度 $\left([\alpha]_{\mathrm{D}}\right)$ 和よび旋光分散法 (ORD), 融点 (m. p.), X線解析, ピエゾ電気法などが ある.これらの方法は Schlenk ${ }^{(8)}$ 和よび $\operatorname{Smith}^{(9)}$ の総 説に詳しい。また，キラルシフト試薬による NMR 法(10)，光学活性力ラムを用いた HPLC 法(11) 報告され ている、しかし，これらの方法は，操作の簡便性や分析 感度の点であまり実用的とは言い難かった。たとえば， 数段階に及ぶ複雑な誘導体化法は，試料を多く必要之 し，簡便ではない， $[\alpha]_{\mathrm{D}}, \mathrm{ORD}$ 法は，簡便ではあるが， グリセりドの対称性のため，その旋光度は小さく正確さ に欠ける. NMR 法は, ピークの重なりのため判読しに くい. キラル HPLC 法は分離に長時間を要する,など といった各々の問題点を残している.

筆者らは, 分光学的立場から, $\mathrm{CD}$ の励起子キラリテ ィー法 ${ }^{(3)}$ 基づいた高感度なグリセリドの絶対配置を 決定する方法を開発した。

a）CD の励起子キラリティー法に基づいたグリセリド の絶対配置の決定(4)

励起子キラリティー法 ${ }^{(3)}$ は，キラルな環状ジベンゾェ ートグリコール化合物の絶対配置を非経験的に決定する 方法であり，天然物の立体化学を決定するのに広く用い られている。この方法は，固定配座系には適用可能であ るが，天然グリセリドから誘導可能な隣接ジベンゾェー トグリセリドのような鎖状化合物にも適用できるか否か は不明であったしかし，後述のように筆者らは，隣接 ジベンゾェートグリセリドが特定の優先安定配座をとる ことを明らかにしだ(4).このことは，非経験的に CD に より感度良く天然グリセリドの立体化学を決定できる可 能性を示唆するものであった。 


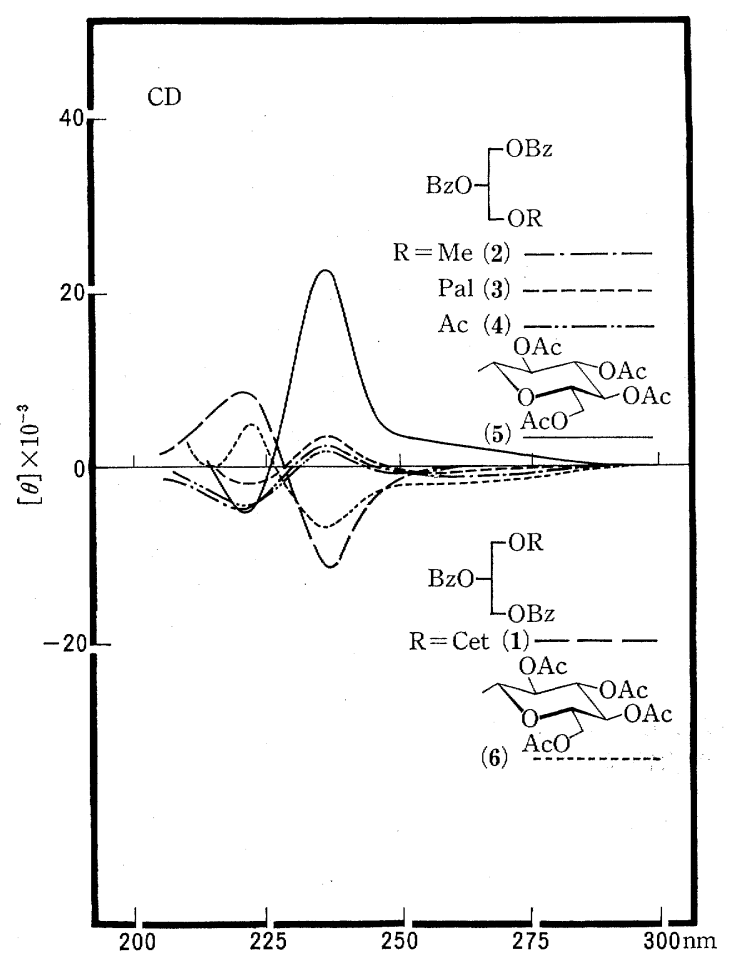

図 1曰化合物 1〜6 のICD スペクトル (メタノール中)

本稿では, 天然グリセリドから誘導可能なモノーOーア

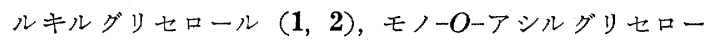
ル $(3,4)$, 天然の 糖脂質を模倣したグリコシルグリセ

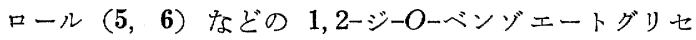

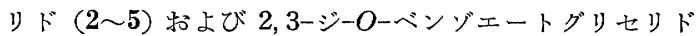
（1，6）をモデル化合物（図 1）に選び，まずはじめにそ
の CD スペクトルによる立体化学の決定法を説明する.

$\mathrm{PAF}^{*}$ のうに天然に広く存在するOーアルキルグリセ リドのモデルとして 1 位にセチル基を持つ化合物 1 の CD スペクトルは, $236 \mathrm{~nm}$ に負の第一コットン効果を, $220 \mathrm{~nm}$ に正の第 2 コットン効果を示す（図 1 ). 1 の2 位に関してエナンチオマーであり，最も単純なアルキル 鎖のメチル基を 3 位に持つ 2 は, 正の分裂型コットン効 果を与えた (図 1 ).ささらに，モノアシルグリセリドのモ デルで短鎖 $(\mathrm{C}=2)$ 和よび長鎖 $(\mathrm{C}=16)$ のアシル基を 各々 3 位に持つ 3 特よび 4 の CD の符号は，すでに述べ たアルキルグリセリド 2 の符号と一致した（図 1 ). す

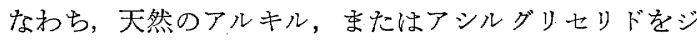
ベンゾェート体に誘導体化後，CD を測定すれば，アル キル基の鎖長数によらず, $\mathrm{CD}$ の符号から絶対配置を決 定できる.

互いに，ジアステレオ関係にある糖グリセリド，5，6 の CD スペクトルは,グリセロール部位の 2 位の絶対配 置を反映した正および負の分裂型コットン効果を各々示 す（図 1 ). この結果は, 1 から4の化合物に適用した法 則と一致している. 本法は, 糖グリセリドのグリセロ一 ル部位の絶対配置を決定するためにも有用な方法である が，天然の糖グリセりドを $5 ， 6$ に誘導体化することは 容易ではない，これについては，後述の「2. 糖グリセリ ドのグリセロール部位の絶対配置の決定」を参照された W.

さらに,この法則は, 3 位に各種置換基 $\left(\mathrm{H}, \mathrm{N}_{3}, \mathrm{Br}\right.$, $\mathrm{OTs}, \quad \mathrm{OSi}^{t} \mathrm{BuMe}_{2}$ ) を導入した 1,2-ジーO-ベンゾイル グリセリドにも適用することがで き，本法が一般性のあることが明ら かとなった.なお，ジベンゾイルグ リセリドの一般合成法を図 2 に示 †.

\section{b) NMR による安定配座解析 ${ }^{(2,4)}$}

先に示したように，1,2-ジーO-ベ ンゾイルグリセリドは，正の分裂型 CD を与える. これは, 2 つのベン ゾイル 発色団が，3つの安定 配座 $(g g, g t, t g)$ のち $g t$.ンンォメー ションであることを示している（図

* 血小板活性化因子
図 2曰天然グリセリドのジーO-ベンソイルグリセリドへの変換経路 i) $\mathrm{BzCl} /$ pyr., DMAP, ii) ${ }^{t} \mathrm{BuMe}_{2} \mathrm{SiCl} /$ pyr., iii) $\mathrm{NaOMe} / \mathrm{MeOH}$ 
3). コンフォマーgt は正の, コン フォマー $g g$ は負の分裂型 CD を各 各与える.したがって, 優先配座の 決定は，天然グリセりドの絶対配置 を決定するときに重要になる。

筆者らは, キラル重水素化グリセ リドを用いて NMR により優先配 座を明らかにした。すなおち，当研 究室のキラル重水素標識化糖を原料 として ${ }^{(12)},(1 S)$-和よび $(1 R)$-配置 に重水素化した光学純度～100\%の キラル重水素化グリセりドを化学的 に合成し(2), NMR により対称性の よい1位と 3 位の識別，和よび本来 区別が困難な proR, proS プロトン の完全な帰属を行ない，NMRによ
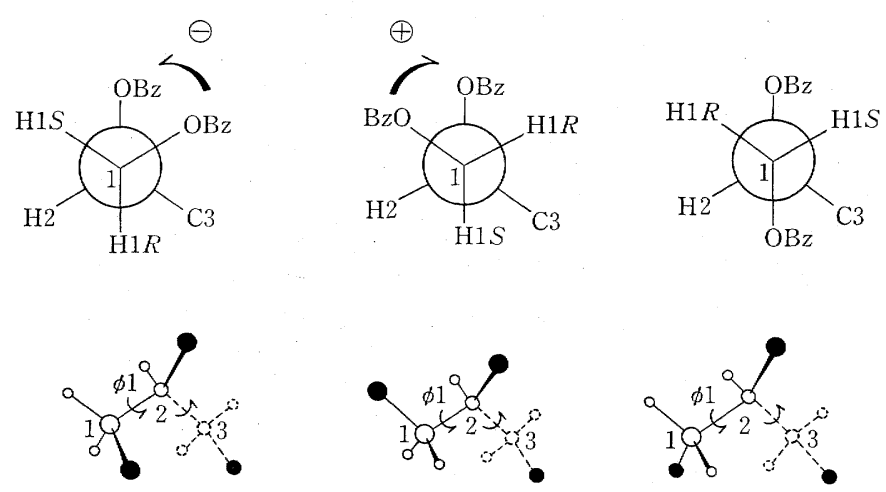

$g g$

$g t$

$\operatorname{tg}$

図 3・1,2-ジ-0-ベンソイルグリセロールの C1-C 2 結合に関する 3 つのコ ンフォマー,gg,gt および $t g$

るグリセりドの配座解析を行なった．その結果，先に示 したモデル化合物のいずれも $g t$ が優先配座であること を明らかにした ${ }^{(4)}$.この結果は，CD の符号と一致する ものである.

本 CD 法は, 従来の ORD 法に比べ感度が 100 倍高 く, 非常に有用な方法といえよう。なお, 筆者らは本法 をリパーゼの 1，3-選択性の決定 ${ }^{(13)}$ 亿応用している.

\section{2. 糖グリセリドのグリセロール部位の絶対配置 の決定 ${ }^{(5,6)}$}

糖グリセリドは, 植物や微生物などに広く分布 $乙^{(14,15)}$, 細胞表層の構成成分, 細胞間の認識などの重要 な役割を担っている.このような糖グリセりドのグリセ ロール部位の絶対配置の決定は, 未知の糖グリセりドの 構造決定や，生理作用との関係を明らかにする上で必要 不可欠である.これまでの分析法としては，大別して 3

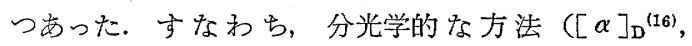
$\left.\mathrm{IR}^{(17)}, \mathrm{NMR}^{(18)}\right)$, クロマト法 (GC, HPLC(19)), 誘導体 化法（酸化 ${ }^{(20)}$ ，×チル化 ${ }^{(21)}$ ) である. しかし，いずれも 多くのサンプルを必要とし，またグリセロールの対称性 から, 糖グリセリドそのもの, もしくは, 酸加水分解に より得られるアキラルなグリセロールを分析しても，有 用な情報は得られなかった。 また，前述のジベンゾイル 化法も適用がとれほど容易ではないので，筆者らは，(1) 高分解能 $\mathrm{NMR}^{(5)}$ ，拉よび(2) ORD， $\mathrm{CD}^{(6)}$ を用いた糖グ
リセリドのグリセロール部位の絶対配置決定法なる別の 方法を開発した。

a ） ${ }^{1} \mathrm{H}-\mathrm{NMR}$ によるリゾ糖グリセリドのグリセロール 部位の絶対配置の決定 ${ }^{(5)}$

糖グリセリドの中にはへモリジン(15)をはじめとして リゾ体（モノーOーアシル体）として天然に存在するもの が多い，そのグリセロール部位の絶対配置を明らかにす る目的で, 飽和脂肪酸 $\left(\mathrm{C}_{18: 0}\right)$ を持つ 3-O-ガラクトシ ルー1-O-アシルグリセリド拉よび 1-O-ガラクトシル-3Oーアシルグリセリド，拉よび高度不飽和脂肪酸 $\left(\mathrm{C}_{18: 1}\right.$, $\left.\mathrm{C}_{18: 2}, \mathrm{C}_{18: 8}, \mathrm{C}_{20: 5}\right)$ を有するグリコシルモノアシルグリ セりドの $2 R, 2 S$ 両体を化学的に合成し，それらの ${ }^{1} \mathrm{H}-\mathrm{NMR}(400 \mathrm{MHz}$, 重メタノール)を比較したとこ ろ, 両ジアステレオマーは, アシル基の種類によらず, グリセロールの 2 位の絶対配置を反映した特徵的な化学 シフト, 結合定数, および分裂様式を示すことがわかっ た（図 4).1-O-ガラクトシルー3-O-アシルグリセリドの 特徵は, グリセロール 部位の $\mathrm{H}-3^{\prime} \mathrm{a}, \mathrm{H}-3^{\prime} \mathrm{b}$ の 2 つの プロキラルなプロトンが完全に分離した形で観測された こと，H-1' proR プロトンが $3.57 \mathrm{ppm}$ で共鳴し，対応 するジアステレオマーと比べて比較的高磁場にあるこ そ，そのため $\mathrm{H}-2, \mathrm{H}-5, \mathrm{H}-3$ のプロトンの共鳴位置に 観測されたこと，さらに $\mathrm{H}-2^{\prime}$ と $\mathrm{H}-1^{\prime}$ a の一部が重な ク， H-2' 性複雑な分裂様式を示すことである. 


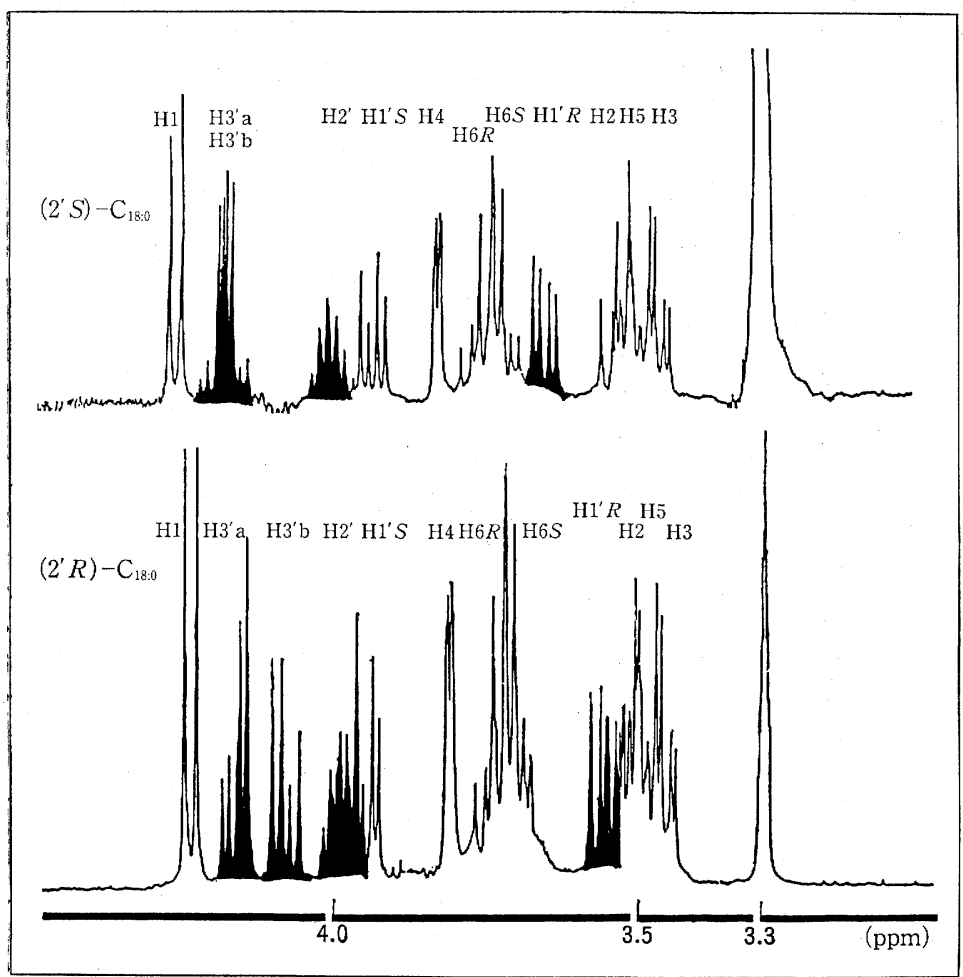

図 4 - $\left(2^{\prime} S\right)$-および $\left(2^{\prime} R\right)-C_{18: 0}$ モノガラクトシルモノグリセリドのガラク トースおよびグリセロール部分の $400 \mathrm{MHz}^{1} \mathrm{H}$ NMR スペクトル $\left(\mathrm{CD}_{3} \mathrm{OD}\right.$ 中)
一方 3-O-グリコシルグリセリドで は各々 $5.2,4.5 \mathrm{~Hz}$ と，その值が 両者で大きく異なっている.このよ らに，2つのジアステレオマーは， グリセロール部位の 2 位の絶対配置 を反映した NMR スペクトルを与 え，両スペクトルを比較することに より糖グリセリドのグリセロール部 位の立体化学を決定できる.

本法の特徴は，天然物を用いて非 破壊的に絶対配置を決定できること である。

b ） ORD, CD 法による糖グリセリ ドのグリセロール部位の絶対配置の 決定 $^{(6)}$

糖グリセリドのグリセロール部位 の絶対配置を決定する簡便で一般性 が高く実用的な分析法を開発した ${ }^{(6)}$. 本法は, (1)糖グリセリド ( 7 ) の perO-benzylation ( 8 ), (2)酸加水分解 による ジーO-ベンジルグリセロール
結合定数においても，大きな違いが見られた，ガラク トース部位の差はほとえど見られないのに対し，グリセ ロール部位に括ける $J H 1^{\prime}$ proS, $H 2^{\prime}, J H 1^{\prime}$ proR, $H 2^{\prime}$ は, 1Oーグリコシルグリセリドでは各々 $4.3,6.5 \mathrm{~Hz}$ であり,
(9) への誘導, および(3) ORD または CD 測定からな る(図 5).これは，(1)ベンジル基が導入しやすく，ま た通常の酸加水分解に対して安定であること, (2) UV 発色団として機能するため TLC または LC 分取が可能
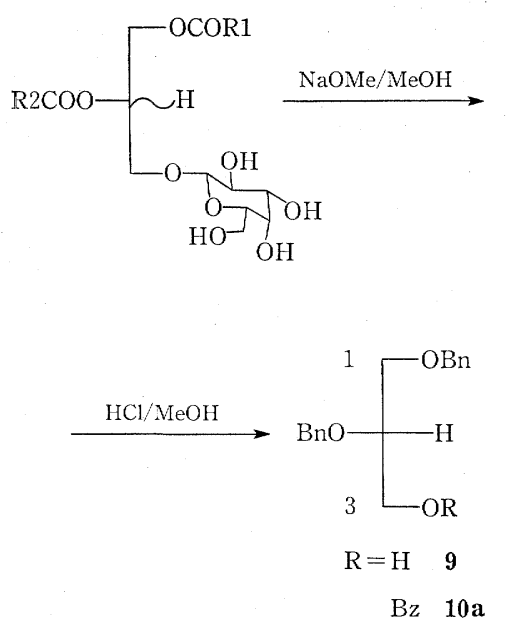
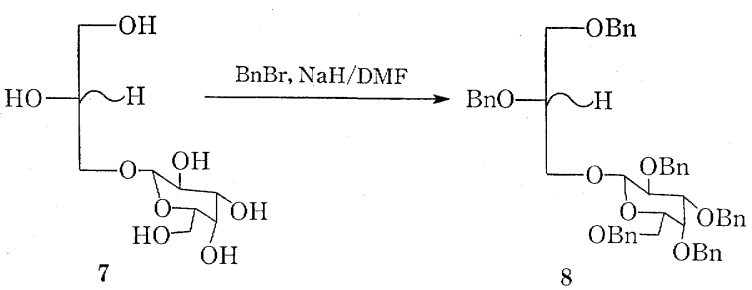

8

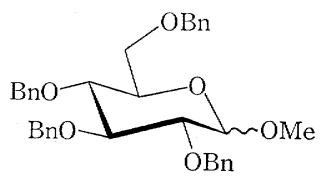

$$
\begin{aligned}
\mathrm{R}=\mathrm{H} & \mathbf{9}^{\prime} \\
\mathrm{Bz} & \mathbf{1 0 ^ { \prime } \mathbf { a }}
\end{aligned}
$$

図 5ログリコシルグリセリドのジーO-ベンジルグリセリド $\left(9,9^{\prime}\right)$ への変換経路 


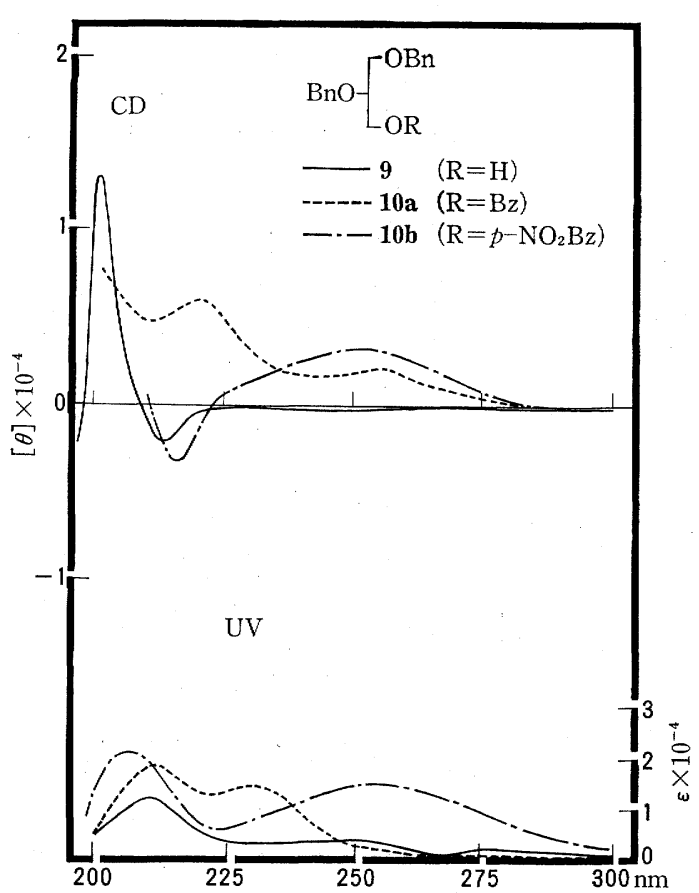

図 6曰1,2-ジ-O-ベンジルグリセロール（9）およびそ の 3-O-ベンゾイル化誘導体 $(10 \mathrm{a}, 10 \mathrm{~b})$ の CD および UV スペクトル (メタノール中)

なこと，(3)化合物 9 の $[\alpha]_{\mathrm{D}}$ が既知でその值が大きい こと(17)を利用したものである. $[\alpha]_{\mathrm{D}}$ 蛒よび ORD の測 定は, 最も旋光強度が大きく短波長領域でも測定可能な nーヘキサンが良好な結果を与兄た。

感度を高めるには，CD 法が一般によいが，9 の CD は, $216 \mathrm{~nm}$ に小さな負の, $203 \mathrm{~nm}$ に大きな正のコット ン効果を与克た（図 6)。乙かし，強いUV 吸収による ノイズと測定の困難さのため， $203 \mathrm{~nm}$ のコットンから グリセロール部位の立体化学を決定するには無理があっ た．そこで，CD 強度を増大させ，同時にコットン効果 を長波長シフトさせるために， $p-\mathrm{NO}_{2} \mathrm{Bz}$ 基 $(10 \mathrm{~b})$ をさ らに導入したところ，ベンゾイル基（10 a) よりはコッ トン効果は小さかったが $(+3600(250 \mathrm{~nm})), 225 \sim 275$ $\mathrm{nm}$ にかけて幅広い $\mathrm{CD}$ バンドが観測され，測定しやす いことがわかった。

本法の応用として， $\beta$-ガラクトシダーゼによる ${ }^{(22)}$ ラクトースのグリセロールへの転移反応の立体選択性 を研究したところ，酵素反応のジアステレオ選択性は $56 \%$ d.e. で，グリセロールの 3 位に優位に転移してい ることを明らかにすることができた。
以上，筆者らの行なってきたグリセりドの絶対配置の 決定について紹介してきたが，本稿にまとめたことが今 後の研究の一助になれば幸いである。

ß-ガラクトシダーゼ反応により得られたガラクトシルグリ セロールを供与してくださった大阪市立工業研究所研究員の中 野博文博士に深謝いたします。

\section{文献}

1) V.M. R.-Mercadillo \& G. M. Whitesides : J. Am. Chem. Soc., 101, 5828 (1979).

2) (a) H. Uzawa, Y. Nishida, S. Hanada, H. Ohrui \& H. Meguro:J.Chem. Soc., Chem. Commun., 1989, 863.

(b) Y. Nishida, H. Uzawa, S. Hanada, H. Ohrui \& H. Meguro : Agric. Biol. Chem., 53, 2319 (1989).

3) N. Harada \& K. Nakanishi : "Circular Dichroic Spectroscopy Exciton Coupling in Organic Stereochemistry", Univ. Sci. Books, CA, 1983.

4) H. Uzawa, Y. Nishida, H. Ohrui \& H. Meguro : J. Org. Chem., 55, 116 (1990).

5) 渡辺正人：東北大学大学院修士論文 (1987).

6) H. Uzawa, Y. Nishida, H. Ohrui \& H. Meguro : Agric. Biol. Chem., 53, 2327 (1989).

7) H. Brockerhoff : J. Lipid Res., 8, 167 (1967).

8) W. Schlenk, Jr.: J. Am. Oil Chem. Soc., 42, 945 (1965).

9) C. R.Smith, Jr.: Top. Lipid Chem., 3, 89 (1972).

10) J.Bus, C. M. Lok \& A. Groenewegen : Chem. Phys. Lipids, 16, 123 (1976).

11) (a) T. Takagi \& Y. Itabashi : Lipids, 22, 596 (1987). (b) T. Shibata, I. Okamoto \& K. Ishii : J. Liq. Chromatogr., 9, 313 (1986).

(c) Y. Okamoto \& K. Hatada : J. Liq. Chromatogr., 9, 369 (1986).

12) (a) 目黒 熙, 大類 洋: 化学之生物, 24, 583 (1986). (b) H. Hori, T. Nakajima, Y. Nishida, H. Ohrui \& H. Meguro: J.Carbohydr. Chem., 5, 585 (1986) and references are therein.

13) H. Uzawa, Y. Nishida, H. Ohrui \& H. Meguro: Biochem. Biophys. Res. Commun., 168, 506 (1990).

14) D. A. Mannock, R. N. A. H. Lewis \& R. N. McElhaney : Chem. Phys. Lipids, 55, 309 (1990) and references are therein.

15) (a) H. Kozakai, Y. Oshima \& T. Yasumoto: Agric. Biol. Chem., 46, 233 (1982).

(b) 安元 健: 有機合成化学協会誌, 46, 478 (1988).

16) B. Wickberg: Acta Chem. Scand., 12, 1187 (1958).

17) H. Wehrli \& Y. Pomeranz: Chem. Phys. Lipids, 3, 357 (1969).

18) J.Meng, K. G. Rosell \& L. M. Srivastava : Carbohydr. Res., 161, 171 (1987).

19) (a) D.E. Brundish \& J. Baddiley: Carbohydr. Res., 8, 308 (1968).

(b) D. A. Mannock, R. N. Lewis \& R. N. McElhaney : Chem. Phys. Lipids, 43, 113 (1987).

20) D. E. Brundish, N. Shaw \& J.Baddiley:Biochem. J., 97, 158 (1965).

21) T. Sawai \& E. J. Hehre : J. Biol. Chem., 237, 2047(1962).

22) 中野博文: 科学と工業, 63，407 (1989). 